\title{
Characterization of a New Tymovirus Causing Stunting and Chlorotic Mosaic in Naranjilla (Solanum quitoense)
}

Kelsie J. Green, Department of Entomology, Plant Pathology and Nematology (EPPN), University of Idaho, Moscow; Dimitre Mollov, United States Department of Agriculture-Agricultural Research Service, National Germplasm Resources Laboratory, Beltsville, MD; Lisa T. Tran, Department of EPPN, University of Idaho; Robert A. Alvarez-Quinto, Centro de Investigaciones Biotecnológicas del Ecuador and Facultad de Ciencias de la Vida, Escuela Superior Politécnica del Litoral, ESPOL, Guayaquil, Ecuador; Jose B. Ochoa, Instituto Nacional Autónomo de Investigaciones Agropecuarias, Quito, Ecuador; Diego F. Quito-Avila, Centro de Investigaciones Biotecnológicas del Ecuador and Facultad de Ciencias de la Vida, Escuela Superior Politécnica del Litoral; and Alexander V. Karasev, ${ }^{\dagger}$ Department of EPPN and Bioinformatics and Computational Biology Program, University of Idaho

\begin{abstract}
Naranjilla ("little orange"), also known as lulo (Solanum quitoense Lam.), is a perennial shrub species cultivated in the Andes for fresh fruit and juice production. In 2015, a naranjilla plant exhibiting stunting, mosaic, and chlorotic spots was sampled in the Pastaza province of Ecuador and maintained under greenhouse conditions. An infectious agent was mechanically transmitted to indicator plants and was subjected to biological and molecular characterization. Spherical particles approximately $30 \mathrm{~nm}$ in diameter, composed of a single 20-kDa capsid protein, were observed under an electron microscope in infected naranjilla plants. Highthroughput sequencing conducted on inoculated Nicotiana benthamiana plants produced a single sequence contig sharing the closest relationship with several tymoviruses. The entire 6,245-nucleotide genome of a new

tymovirus was amplified using reverse-transcription polymerase chain reaction and resequenced with the Sanger methodology. The genome had three open reading frames typical of tymoviruses, and displayed a whole-genome nucleotide identity level with the closest tymovirus, Eggplant mosaic virus, at $71 \%$ (90\% coverage). This tymovirus from naranjilla was able to systemically infect eggplant, tamarillo, $N$. benthamiana, and naranjilla. In naranjilla, it produced mosaic, chlorotic spots, and stunting, similar to the symptoms observed in the original plant. The virus was unable to infect potato and tobacco and unable to systemically infect pepper plants, replicating only in inoculated leaves. We concluded that this virus represented a new tymovirus infecting naranjilla, and proposed the tentative name Naranjilla chlorotic mosaic virus (NarCMV).
\end{abstract}

Naranjilla, also called lulo (Solanum quitoense Lam.), is a perennial shrub species cultivated in subtropical areas of Ecuador and Colombia. The naranjilla fruit pulp is rich in vitamins $\mathrm{A}, \mathrm{C}$, and $\mathrm{K}$, and provides an important dietary supplement, which is nutritionally similar to orange juice (Acosta et al. 2009; Gancel et al. 2008). In Ecuador, naranjilla is grown on approximately 10,000 ha and constitutes the main income source for thousands of families in the provinces of Tungurahua, Napo, Pastaza, and Morona Santiago in the Amazon region. Production has increased significantly in the past two decades and naranjilla is now widely available as fresh fruit, juice, and a flavoring for other products such as ice cream. Pests and diseases affect naranjilla production and limit potential benefits and income from the crop by local farmers. Vascular wilt caused by the soilborne pathogen Fusarium oxysporum and the root knot nematode (Meloidogyne spp.) are the major problems in "common naranjilla" (S. quitoense) production (Monteros et al. 2004; Ochoa et al. 2001). The severity of these pathogens led to important changes in the cropping systems such as grafting scions onto resistant rootstock and development of interspecific hybrids (Integrated Pest Management Innovation Lab 2013). One of these hybrids, known as Puyo (S. sessiliflorun $\times$ S. quitoense), has become the "cultivar" of choice in most production areas of the Amazon region (Dennis and Herner

${ }^{\dagger}$ Corresponding author: A. V. Karasev; E-mail akarasev@uidaho.edu

Funding: This work was funded, in part, through grants from the United States Department of Agriculture (USDA) Agricultural Research Service (58-8042-6-049), USDA National Institute for Food and Agriculture Hatch (project IDA01560), and by the Idaho Agricultural Experiment Station.

*The $\boldsymbol{e}$-Xtra logo stands for "electronic extra" and indicates that one supplementary table is published online.

Accepted for publication 25 November 2017.

(c) 2018 The American Phytopathological Society
1985; Heiser and Anderson 1999). However, the small size of its fruit has challenged breeders to develop hybrids with both good agronomic and disease resistance traits.

Thus far, there have been no reports of viral infections in naranjilla. Among the possible reasons for this could be the lack of prominent symptoms, latent infections, or simply an underestimation of the potential damage caused by these pathogens, especially when present in mixed infections. Furthermore, the vegetative propagation nature of common interspecific hybrids poses a direct threat to the sustainability of this crop due to the lack of naranjilla certification programs. In addition, the continuous search for hybrids and varieties endowed with optimal production traits may trigger the appearance of new or reemerging viruses, which are usually symptomless in wild species. Symptomatic (mosaic, mottling, leaf deformation, and stunting) tamarillo (S. betaceum), a fruit crop commonly grown side-byside with naranjilla and other solanaceous crops in the Amazon region, was recently reported as infected with Potato virus $Y$, Potato virus $V$, and Potato leafroll virus, and others traditionally considered potato viruses (Espinoza et al. 2017; Insuasti et al. 2016).

This prompted us to investigate the virus status of naranjilla hybrid Puyo in the main production areas of Ecuador, using several approaches. This study reports a novel tymovirus, provisionally named Naranjilla chlorotic mosaic virus (NarCMV). The objectives of this study were to characterize the host range of this new virus, determine its genome organization and phylogenetic relationship with known viruses, and develop methods for its detection.

\section{Materials and Methods}

Virus origin and maintenance. In 2015, several naranjilla cultivars, including the Puyo hybrid, were collected from Pastaza province and greenhouse propagated at the Ecuadorean Agricultural Research Institute (Instituto Nacional Autónomo de Investigaciones Agropecuarias) in Santa Catalina, Quito, Ecuador. Plants were monitored for virus-like symptoms. One sample from the Puyo hybrid exhibited mosaic and chlorotic spots. Symptomatic leaves were ground in $50 \mathrm{mM}$ sodium phosphate buffer, $\mathrm{pH} 7.0$, plus $20 \mathrm{mM}$ sodium sulfite, and mechanically inoculated onto Nicotiana benthamiana plants, 
which developed virus-like symptoms. The isolate was maintained in $N$. benthamiana through periodic reinoculations into young healthy plants at the four- to six-leaf stage.

Physicochemical characterization and antisera production. The virus was purified using a modification of the protocol described by Dunn and Hitchborn (1965). Briefly, $50 \mathrm{~g}$ of systemically infected $N$. benthamiana leaves were homogenized in $100 \mathrm{ml}$ of cold bentonite preparation mixed with $0.1 \mathrm{M} \mathrm{MgSO}_{4}(\mathrm{pH}$ 7.4). Leaf homogenate was squeezed through cheesecloth and subjected to two cycles of differential centrifugation consisting of low speed centrifugation for 15 min at 21,000 $\times g_{\max }$ in a JLA16.250 rotor (Beckman Avanti J-25) to separate the bentonite and $70 \mathrm{~min}$ at $64,000 \times \mathrm{g}$ in a Ti45 rotor (Beckman) to pellet the virus. The final pellet was resuspended in buffer (0.05 M MgSO $\left.4+0.01 \mathrm{M} \mathrm{Na}_{2} \mathrm{HPO}_{4}+0.01 \mathrm{M} \mathrm{KH}_{2} \mathrm{PO}_{4}, \mathrm{pH} 7.4\right)$, and stored at $4{ }^{\circ} \mathrm{C}$ with $0.1 \%$ sodium azide.

Dilutions of the purified virus were separated in 4 to $20 \%$ gradient sodium dodecyl sulfate (SDS)-polyacrylamide gels (Bio-Rad) and stained using Coomassie Brilliant Blue G-250 (Bio-Rad). Two protein marker sets were used: an SDS polyacrylamide gel electrophoresis (PAGE) broad-range standard (Bio-Rad catalog number 161-0318) and a Precision Plus Protein Dual Color standard (Bio-Rad catalog number 161-0374). The major protein band was excised from the gel, subjected to in-gel trypsin digestion, and analyzed using the liquid chromatography tandem mass spectrometry (LC-MS/MS) proteomics instrument at the Food Research Center of the University of Idaho, according to the previously described protocol (Hanson et al. 2016). Mascot v2.5 software (Matrix Science) was used for MS/MS ion matching and protein identification.

The bentonite-purified virus preparation was also used for antisera production by Cocalico Biologicals in rabbit and in mouse, after a series of three intramuscular and subcutaneous injections with Freund's adjuvant. The resulting antisera were tested against infected and healthy $N$. benthamiana plants using a triple-antibody sandwich enzyme-linked immunosorbent assay (TAS-ELISA) according to the methodology of Clark and Adams (1977), with some modifications as described by Nikolaeva et al. (2012). Specificity of polyclonal antibodies was initially tested against symptomatic (inoculated) or healthy (noninoculated) $N$. benthamiana leaf tissue in TAS-ELISA. The two antisera, UID-41 (rabbit) and UID-M28 (mouse), were used to develop a TAS-ELISA-based detection protocol. Plant extracts were obtained by grinding leaf tissue in an ELISA extraction buffer (Nikolaeva et al. 2012). These extracts, as well as purified virus preparations, were analyzed using 4 to $20 \%$ gradient polyacrylamide gel electrophoresis (PAGE) (Bio-Rad) followed by Coomassie staining as described above, or by Western blots. For Western blot, proteins separated by PAGE were transferred to nitrocellulose membranes and probed with the putative NarCMV antibody, as described previously (Karasev et al. 2010).

Biological characterization. Infected $N$. benthamiana plants were used as a source to inoculate six plant species: $S$. quitoense Lam. (naranjilla), S. melongena 'Fairy Tale' (eggplant), S. betaceum (tamarillo), and three additional solanaceous species: N. tabacum 'Burley' (tobacco), Capsicum annuum 'Early California Wonder' (pepper), and S. tuberosum 'King Edward' (potato). All plants were grown in an insect-proof growth room at 23 to $26^{\circ} \mathrm{C}$ before and after inoculations, under artificial light provided by fluorescent and incandescent lamps with a day-and-night cycle of 18 and $6 \mathrm{~h}$, respectively. Plants were mechanically inoculated at the four- to six-leaf stage and observed for symptoms every 4 to 5 days after inoculation for 6 to 8 weeks. Three plants per species or cultivar were tested in a single experiment which always included healthy control plants. RT-PCR was used to confirm the results from visual observations using two primers used for sequencing, tymo1294F and tymo2278R, which amplify a 1-kb fragment within the overlapping 69- to 200-kDa polyprotein $(69 \mathrm{~K}$ to $200 \mathrm{~K})$ genes. Total RNA was extracted from $200-\mathrm{mg}$ samples of inoculated ( 7 to 10 days postinoculation) and upper noninoculated ( 3 to 4 weeks postinoculation [wpi]) leaves using the Dellaporta extraction protocol (Dellaporta et al. 1983).

Transmission electron microscopy. Symptomatic leaves ( 3 to 5 g) were harvested from mechanically inoculated naranjilla, tamarillo, eggplant, and $N$. benthamiana 18 wpi and used for partial virion purification and transmission electron microscope (TEM) observations. Leaves were ground in liquid nitrogen and suspended in four volumes (wt/vol) of $0.5 \mathrm{M}$ sodium phosphate buffer, $\mathrm{pH} 7.4$, containing $1 \mathrm{M}$ urea, 5\% (wt/vol) PVP-40, and 0.5\% (vol/vol) 2-mercaptoethanol. Plant extracts were filtered and the liquid was centrifuged at $19,800 \times$ $g_{\max }$ for $10 \mathrm{~min}$. Triton X-100 (5\%, vol/vol) was added to the supernatant and was left at $4{ }^{\circ} \mathrm{C}$ overnight to allow additional precipitation. Samples were centrifuged again at $19,800 \times g_{\max }$ for $10 \mathrm{~min}$. The supernatant was layered over a $30 \%$ sucrose cushion and centrifuged at $109,000 \times g_{\max }$ for $2 \mathrm{~h}$ at $10^{\circ} \mathrm{C}$. The resulting pellets were resuspended in $0.3 \mathrm{ml}$ of $0.1 \mathrm{M}$ sodium phosphate buffer, $\mathrm{pH} 7.4$, and vortexed with an equal volume of chloroform. The resulting emulsion was centrifuged at $18,400 \times g_{\max }$ for $20 \mathrm{~min}$ and the upper aqueous phase containing virions was applied to formvar-coated carbon grids. Grids were stained with $2 \%$ sodium phosphotungstate, $\mathrm{pH} 7.0$, and visualized on a Hitachi 7700 transmission electron microscope at the Electron and Confocal Microscopy Unit, United States Department of Agriculture-Agricultural Research Service, Beltsville Agricultural Research Center.

High-throughput sequencing, Sanger sequencing, and sequence analysis. Symptomatic $N$. benthamiana leaves were used as a source for the high-throughput sequencing (HTS) analysis. Total RNA was extracted by a Qiagen RNA plant mini kit and sent for cDNA library construction and sequencing to SeqMatic. HTS was performed on a NextSeq 500 Illumina platform as single 75-bp reads. The raw HTS reads were trimmed and assembled into contigs by CLC Workbench 9.0.

Sanger sequencing was performed on a series of overlapping RTPCR fragments amplified on total RNA extracted from the infected $N$. benthamiana plants via the Dellaporta method, essentially as described previously (Green et al. 2017). Primers used to amplify these DNA fragments are listed in Supplementary Table S1. PCR fragments were treated with ExosapIt (Affymetrix) and submitted for sequencing to Genewiz, Inc. The $5^{\prime}$ terminus was amplified using the $5^{\prime}$ RACE Kit (Roche) according to the manufacturer's instructions using primers tymo1008R and tymo180R. To amplify the $3^{\prime}$ terminus of the genome, total RNA was polyadenylated using Escherichia coli Poly(A) Polymerase (New England Biolabs) according to manufacturer's instructions, the first cDNA strand was synthesized using an anchored oligo(dT) primer, and then PCR was conducted using the tymo5975F and tymo5566F forward primers in combination with the anchored oligo(dT) reverse primer. The sequence contigs obtained were assembled using the SeqMan Pro program of the Lasergene 9 program suite (DNASTAR).

For the multiple sequence alignment, MUSCLE (Edgar 2004) implemented in the program MEGA, version 7 (Kumar et al. 2016), was used with the default parameters. Complete genomes (one representative isolate per species), available at the National Center for Biotechnology Information GenBank, from all genera within the family Tymoviridae were used for analysis (Table 1). Phylogeny inference was conducted based on the aligned whole genomes using the maximum-likelihood method implemented in MEGA 7, after using its model selection function to change the appropriate model parameters (Kumar et al. 2016). All nodes with $<70 \%$ support were collapsed. The tRNA secondary structure was predicted using RNAfold (Lorenz et al. 2011)

\section{Results}

Biological characterization. The new virus from naranjilla systemically infected eggplant, $N$. benthamiana, tamarillo, and naranjilla (Fig. 1; Table 2). The infection in Fairy Tale eggplant was essentially symptomless, producing only transient mild mosaic 3 to 5 wpi. Nevertheless, virus titer remained high in infected eggplant, easily detected by RT-PCR and also by TEM up to 18 wpi. In N. benthamiana, the virus induced severe mosaic, vein clearing, and chlorotic spots, which became visible at 2 wpi (Fig. 1A) and later developed into blistering, curling, and other leaf deformations. In common naranjilla, the virus produced mosaic and stunting, visible by 4 wpi; chlorotic spots formed on upper uninoculated leaves, which eventually necrotized and fell off, leaving a perforated leaf surface (Fig. 1B). The symptoms in inoculated naranjilla maintained in the 
growth room were similar to those observed in the plant from which the virus was originally isolated. In tamarillo, the systemic spread of the virus was very rapid, inducing visible mosaic 7 to 10 days postinoculation. Later, at 3 to $5 \mathrm{wpi}$, the virus produced bright chlorotic mosaic and yellowing in upper uninoculated leaves of the plant, with small necrotic lesions becoming visible at 8 wpi (Fig. 2C). No stunting associated with the virus symptoms was observed in infected tamarillo plants for the 18 weeks of observation (Table 2). The virus did not systemically infect potato, tobacco, or pepper, although virus was easily detected in inoculated leaves of pepper plants. Interestingly, these inoculated pepper plants had retarded growth despite the apparent absence of the virus in upper, uninoculated leaves. The results of the host range study are summarized in Table 2.

TEM, virus purification, LC-MS/MS analysis, and immunodetection. Spherical particles, approximately $30 \mathrm{~nm}$ in diameter, were observed under TEM in infected naranjilla (Fig. 2A), tamarillo, eggplant, and $N$. benthamiana plants (not shown). The particles, revealed by negative staining, contained a mixture of intact and empty isometric particles, typical of tymovirus morphology (Koenig and Lesemann 1979). The purification protocol utilizing bentonite applied to infected $N$. benthamiana plants resulted in a virus preparation producing a single major protein band of approximately $20 \mathrm{kDa}$ in SDS-PAGE (Fig. 2B). When this protein band was subjected to the LC-MS/MS analysis, a 9-amino-acid (aa) peptide (LSSPLLQAS) was identified by Mascot among the products of digestion with the highest score of 31 . This peptide matched the C-terminal peptide in the capsid protein (CP) of Chiltepin yellow mosaic virus (ChiYMV), a tymovirus isolated from pepper (Pagán et al. 2010). The combination of morphological characteristics (Fig. 2A), the approximately $20-\mathrm{kDa}$ size of the CP (Fig. 2B), and the presence of the 9-aa peptide in the $\mathrm{CP}$ matching the $\mathrm{C}$-terminus of a known tymovirus, ChiYMV, indicated that the virus isolated from naranjilla in Ecuador may belong to the genus Tymovirus.
The purified virus preparation was used as an antigen for the production of two antisera, in rabbit and in mouse. The antisera displayed high titers against the virus in the infected $N$. benthamiana plants, allowing the use of the rabbit antiserum for coating at the $1: 20,000$ dilution and the mouse antiserum for detection at the 1:30,000 dilution. This TAS-ELISA format gave a ratio (infected/ healthy) of absorbance at $405 \mathrm{~nm}$ of up to 29 at $3 \mathrm{~h}$ after the substrate was added, increasing to approximately 35 at $5 \mathrm{~h}$ in the TAS-ELISA format. It allowed detection of the virus in infected leaf tissue extract of $N$. benthamiana, defined as infected plant signal exceeding the healthy plant signal threefold, following dilution of up to $1: 1,000,000$ (Fig. 2C). When used as a detecting antibody in Western blot analysis, the rabbit antiserum bound a single 20-kDa protein band in plant extract from infected $N$. benthamiana (Fig. 2D).

Sequencing and genome analysis. HTS analysis conducted on inoculated $N$. benthamiana plants produced 20,189,606 raw data reads that assembled into 4,221 contigs longer than 500 nucleotides (nt). BLASTn and BLASTx analyses and assembly (Altschul et al. 1990) of these contigs revealed a single contig of 6,214 nt with closest identities to several tymoviruses, particularly Eggplant mosaic virus (EMV). To confirm and complete the sequence of this novel tymovirus, a set of primers was designed for Sanger sequencing based on this initial HTS sequence. The entire 6,245-nt genome of this novel tymovirus was amplified using RT-PCR, as previously described (Green et al. 2017), and resequenced with the Sanger methodology. The sequence has been deposited into GenBank under accession number MG323924.

The sequenced genome was conceptually translated and found to encode three open reading frames (ORF) typical of tymoviruses (Fig. 3A). The largest ORF starts at position 113 and terminates at position 5,560, encoding a $200 \mathrm{~K}$ protein containing replicationrelated domains with presumed methyltransferase, protease, helicase, and RNA-dependent RNA-polymerase (RdRp) activities. A

Table 1. Complete genomes of the virus species from the family Tymoviridae used for phylogenetic analysis ${ }^{\mathrm{a}}$

\begin{tabular}{|c|c|c|c|}
\hline Number & Viruses (standard abbreviation) & GenBank accession & Reference \\
\hline 1 & Eggplant mosaic virus (EMV) & KJ690172 & $\ldots$ \\
\hline 2 & Naranjilla chlorotic mosaic virus (NarCMV) & MG323924 & This article \\
\hline 3 & Andean potato mild mosaic virus (APMMV) & JX508290 & Kreuze et al. 2013 \\
\hline 4 & Chiltepin yellow mosaic virus (ChiYMV) & FN563124 & Pagán et al. 2010 \\
\hline 5 & Tomato blistering mosaic virus (ToBMV) & KC840043 & $\ldots$ \\
\hline 6 & Andean potato latent virus (APLV) & JX508291 & Kreuze et al. 2013 \\
\hline 7 & Tomato yellow blotch virus (ToYBV) & EU779803 & $\ldots$ \\
\hline 8 & Physalis mottle tymovirus (PhyMV) & Y16104 & $\ldots$ \\
\hline 9 & Chayote mosaic tymovirus (ChaMV) & AF195000 & $\ldots$ \\
\hline 10 & Nemesia ring necrosis virus (NeRNV) & AY751778 & Koenig et al. 2005a,b \\
\hline 11 & Anagyris vein yellowing virus (AVYV) & AY751780 & Koenig et al. 2005b \\
\hline 12 & Ononis yellow mosaic virus (OYMV) & J04375 & Ding et al. 1989 \\
\hline 13 & Plantago mottle virus (PIMV) & AY751779 & Koenig et al. $2005 \mathrm{~b}$ \\
\hline 14 & Scrophularia mottle virus (ScMV) & AY751777 & Koenig et al. 2005b \\
\hline 15 & Dulcamara mottle virus (DuMV) & AY789137 & Tzanetakis et al. 2009 \\
\hline 16 & Turnip yellow mosaic virus (TYMV) & X07441 & Morch et al. 1988 \\
\hline 17 & Kennedya yellow mosaic virus (KYMV) & D00637 & Ding et al. 1990a \\
\hline 18 & Okra mosaic virus (OkMV) & EF554577 & Stephan et al. 2008 \\
\hline 19 & Erysimum latent virus (ErLV) & AF098523 & Srifah et al. 1992 \\
\hline 20 & Poinsettia mosaic virus (PnMV) & AB550790 & Okano et al. 2010 \\
\hline 21 & Bombyx mori macula-like virus (BoMV) & AB 186123 & Katsuma et al. 2005 \\
\hline 22 & Grapevine fleck virus $(\mathrm{GFkV})$ & AJ309022 & Sabanadzovic et al. 2001 \\
\hline 23 & Grapevine Syrah virus 1 (GSyV-1) & KP221256 & Glasa et al. 2015 \\
\hline 24 & Olive latent virus $3(\mathrm{OLV}-3)$ & FJ444852 & Alabdullah et al. 2010 \\
\hline 25 & Peach virus $D(\mathrm{PeVD})$ & KY084481 & $\ldots$ \\
\hline 26 & Maize rayado fino virus (MRFV) & KM523134 & Edwards et al. 2015 \\
\hline 27 & Blackberry virus $S$ (BlVS) & FJ915122 & $\begin{array}{l}\text { Sabanadzovic and Abou } \\
\text { Ghanem-Sabanadzovic } 2009\end{array}$ \\
\hline 28 & Oat blue dwarf virus (OBDV) & U87832 & Edwards et al. 1997 \\
\hline 29 & Nectarine virus $M(\mathrm{NeVM})$ & KT273411 & Villamor et al. 2016 \\
\hline 30 & Citrus sudden death associated virus (CSDaV) & AY884005 & Maccheroni et al. 2005 \\
\hline
\end{tabular}

${ }^{a}$ A reference is given if the authors who deposited the respective sequence listed a publication in the GenBank description; ... indicates sequences deposited without a reference. The new tymovirus, Naranjilla chlorotic mosaic virus (NarCMV) characterized in this article, is highlighted in bold. 
smaller ORF almost completely overlaps with the $200 \mathrm{~K}$ protein ORF, starting at position 106 and ending at position 1,998, encoding a $69 \mathrm{~K}$ protein. This $69 \mathrm{~K}$ protein is required for virus spread and also functions as a gene-silencing suppressor (Bozarth et al. 1992; Chen et al. 2004). The 3'-proximal ORF starts at position 5,563 and ends at position 6,129, encoding the 188-aa CP with an estimated molecular weight of $20 \mathrm{kDa}$ (Fig. 3A). The 9-aa C-terminal peptide LSSPLLQAS of this CP matched the partial sequence for the major protein in the purified virus preparation, as determined by LC-MS/ MS (described above). A conserved 16-nt tymoviral sequence known as the "tymobox" was found between positions 5,531 and 5,546, upstream of the CP start codon (Fig. 3A) - this sequence is believed to be involved in the synthesis of the subgenomic RNA expressing the CP (Ding et al. 1990b). The 3'-terminal RNA sequence of $199 \mathrm{nt}$ was predicted to form an extensive secondary structure as revealed by the RNAfold software (Lorenz et al. 2011), resembling tRNA structures characteristic of other tymovirus genomes (Dreher 2009); the CAC valine anticodon was also identified in an exposed loop (Fig. 3B).

When the whole genome of the new tymovirus was compared with the tymovirus sequences available in the GenBank database using the BLASTn program package, the closest match, EMV (Osorio-Keese et al. 1989), had a nucleotide sequence identity level of $71 \%(90 \%$ coverage). This is below the $80 \%$ threshold for the species demarcation in the family Tymoviridae (Dreher et al. 2012). Pairwise comparisons of the amino acid sequence for the $200 \mathrm{~K}$ protein with the corresponding proteins of other tymoviruses produced the highest identity level of $73 \%$ with the EMV protein (93\% coverage), while the RdRp domain of the same $200 \mathrm{~K}$ protein produced the highest identity level of $77 \%$ with the EMV RdRp (100\% coverage). The amino acid sequence of the CP was found only $83 \%$ identical $(87 \%$

Table 2. Summary of the host range studies of the Naranjilla chlorotic mosaic virus (NarCMV)

\begin{tabular}{llcc}
\hline & \multicolumn{2}{c}{ Virus detection, RT-PCR } \\
\cline { 2 - 4 } Host tested & $\begin{array}{c}\text { Symptoms, } \\
\text { systemic }\end{array}$ & $\begin{array}{c}\text { Inoculated } \\
\text { leaves }\end{array}$ & $\begin{array}{c}\text { Uninoculated } \\
\text { leaves }\end{array}$ \\
\hline Naranjilla & $\begin{array}{c}\text { ChlMos, LDef, } \\
\text { LPerf, St }\end{array}$ & + & + \\
Tamarillo & ChlMos, LDef, & + & + \\
Nicotiana benthamiana & Mos, blist & + & + \\
Eggplant, Fairy Tale & Mild mos & + & + \\
Tobacco, Burley & NS & - & - \\
Pepper, Early & St, NS & + & - \\
California Wonder & NS & - & - \\
Potato, King Edward & NS & & + \\
\hline
\end{tabular}

a Virus presence was detected using reverse-transcription polymerase chain reaction (RT-PCR) with primers tymo $1294 \mathrm{~F}$ and tymo2278R; + = presence of the 985-nucleotide band and - indicates no band in the gel.

b Abbreviations of symptoms: ChlMos = chlorotic mosaic, LDef $=$ leaf deformations, LPerf = leaf perforations, $\mathrm{St}=$ stunting, syst. $\mathrm{NL}=$ systemic necrotic lesions, Mos $=$ mosaic, blist $=$ blistering, and NS $=$ no symptoms .
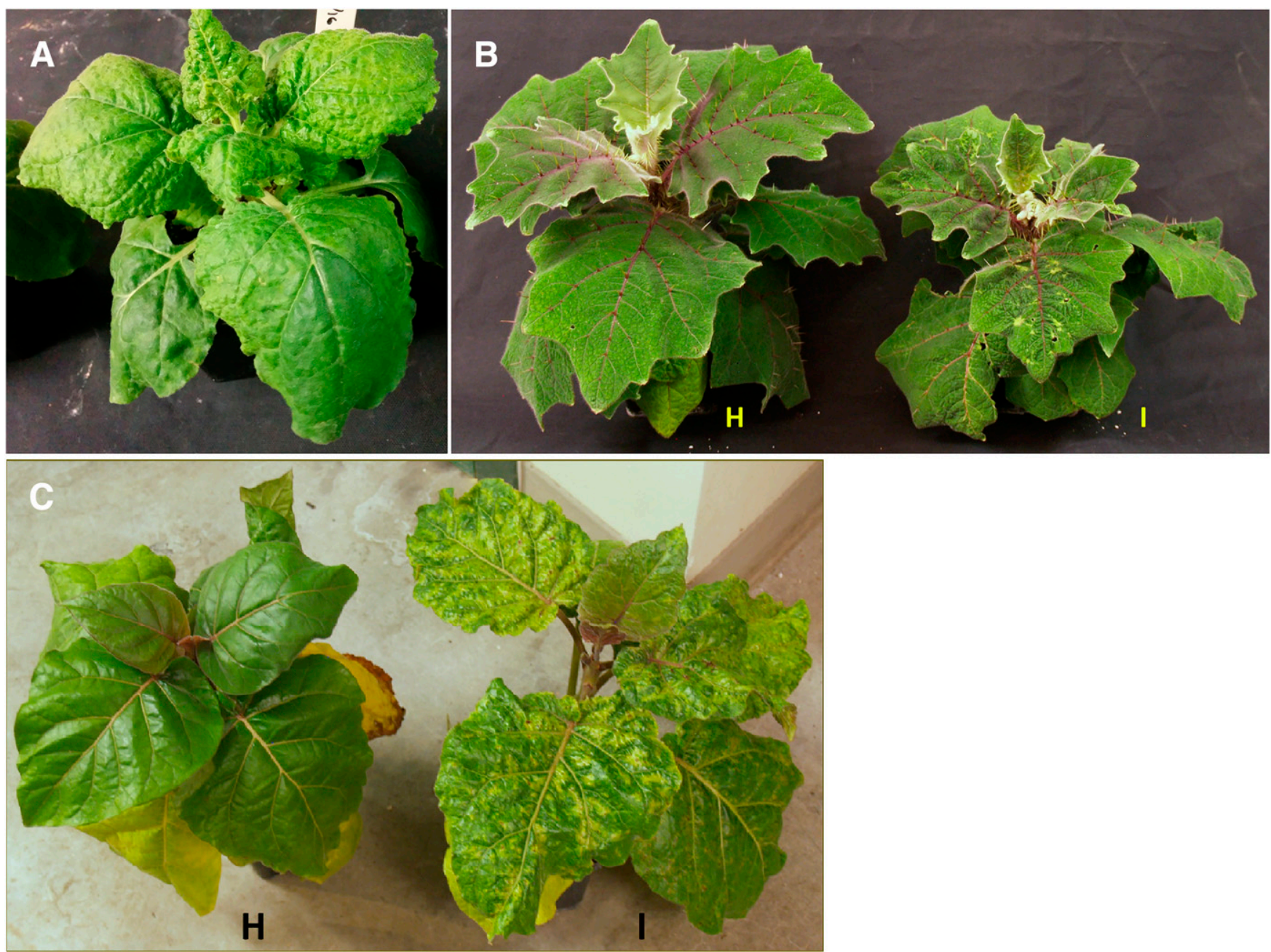

Fig. 1. A, Symptoms of mosaic, blistering, and leaf deformations induced by the new tymovirus in Nicotiana benthamiana, 2 weeks after mechanical inoculation. B, Symptoms of stunting, chlorotic mosaic, leaf deformations, and leaf perforations induced by the new tymovirus in naranjilla (Solanum quitoense), 10 weeks after mechanical inoculation. Healthy plant $(\mathrm{H})$ is on the left and an infected plant $(\mathrm{I})$ is on the right. C, Symptoms of chlorotic mosaic, leaf deformations, and systemic necrotic lesions induced by the new tymovirus in tamarillo (S. betaceum), 9 weeks after mechanical inoculation. Healthy plant $(\mathrm{H})$ is on the left and an infected plant $(\mathrm{I})$ is on the right. 
coverage) to the closest match, ChiYMV, also below the $90 \%$ threshold for the Tymovirus sp. demarcation (Dreher et al. 2012). Phylogenetic analysis of the whole genome of this new virus species placed it within the lineage of the genus Tymovirus, with EMV, another tymovirus infecting solanaceous hosts, as the closest relative (Fig. 4).

\section{Discussion}

During the last two decades, the production of naranjilla has increased significantly in Ecuador. The commercialization of the fruit has gone from small farmers' markets to supermarket chains and juice and ice cream industries. In efforts to develop better cultivars, and considering the low intraspecific variation observed in the "common" naranjilla ( $S$. quitoense), growers and researchers have developed interspecific hybrids that are now widely cultivated. The potential damage caused by virus diseases, however, has not been considered in these new hybrids. The present study reports the complete characterization of a new virus isolated from a symptomatic naranjilla plant found in cultivar Puyo grown in the Pastaza province of Ecuador. The virus was found to be mechanically transmissible, in a very efficient way, to several solanaceous hosts, inducing a range of symptoms from very mild to severe depending on the host. Sequencing and biological data indicated that the virus is a member of the genus Tymovirus in the family Tymoviridae. Nucleotide and amino acid sequence comparisons to the closest relative (EMV) showed percent identities below
A

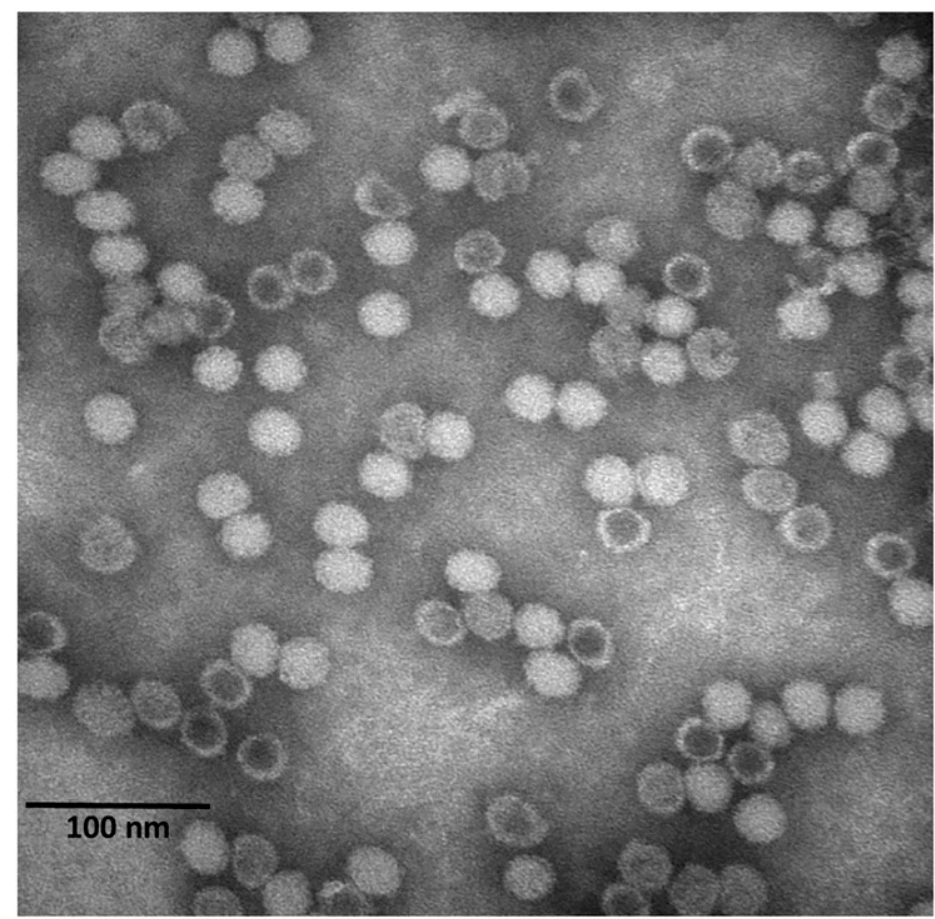

C

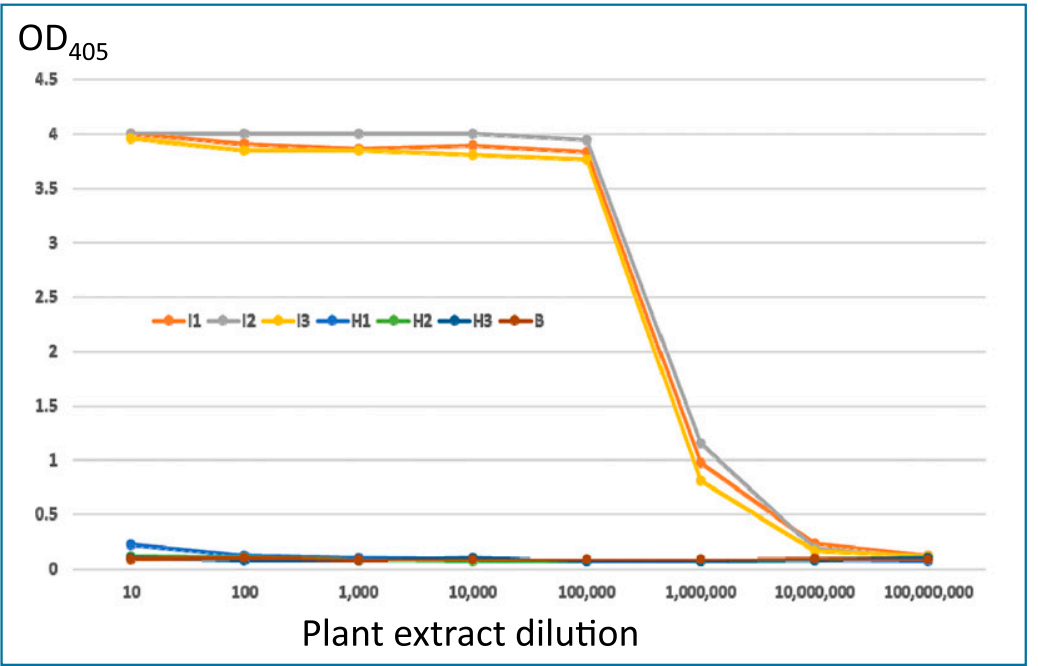

B

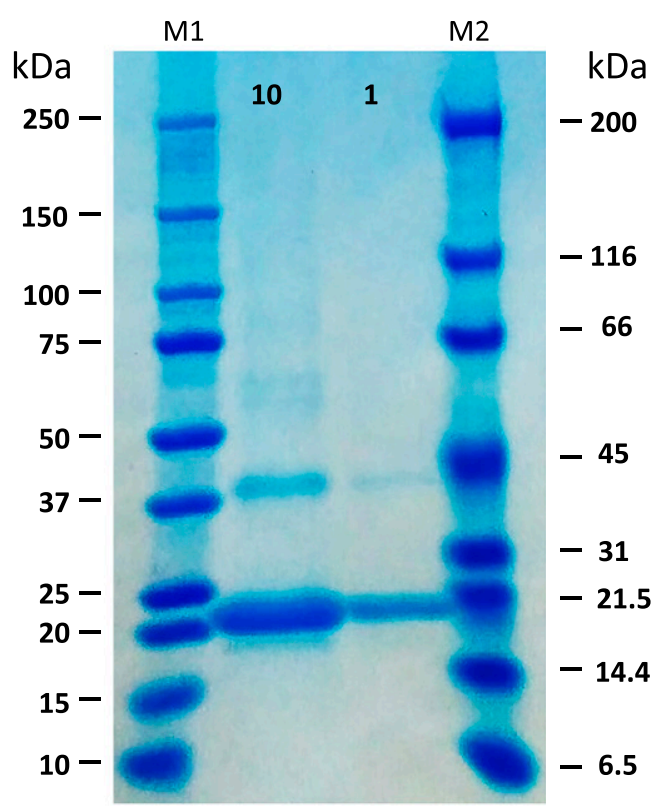

D

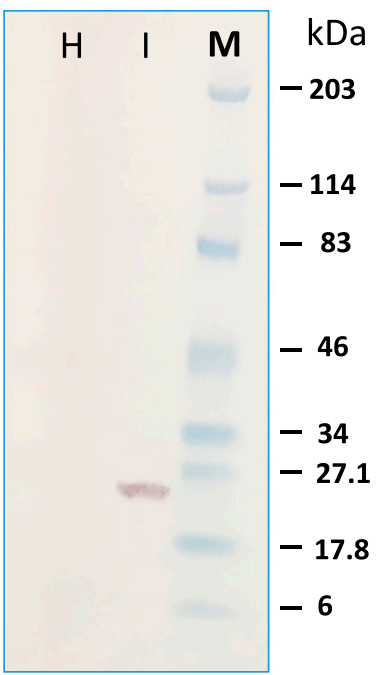

Fig. 2. A, Electron micrograph of the partially purified Naranjilla chlorotic mosaic virus (NarCMV) particles from naranjilla (Solanum quitoense), 18 weeks postinoculation. Negative staining, magnification $\times 120,000$. B, Gradient 4 to $20 \%$ sodium dodecyl sulfate (SDS) polyacrylamide gel analysis of the purified NarCMV preparation, $10 \mu \mathrm{g}$ and $1 \mu \mathrm{g}$ loaded per lane, respectively. M1 and M2 are lanes with protein markers; individual protein sizes are listed next to the bands. C, Titration curves for NarCMV in Nicotiana benthamiana leaves. Detection by triple-antibody sandwich enzyme-linked immunosorbent assay (ELISA); virus antigen was captured by the rabbit UID41 polyclonal antibody (PAb) at 1:20,000 dilution. The mouse UID-M28 PAb was used as detecting antibody at 1:30,000 dilution. The plant extract was titrated along the $X$-axis: leaves of three individual infected (I) and healthy (H) plants were subjected to extraction in a sodium carbonate buffer at 1:10 (wt/vol) ratio; these extracts were diluted prior to loading onto the ELISA plate as indicated along the $x$-axis. $\mathrm{OD}_{405}=$ optical density at $405 \mathrm{~nm}$. D, Western blot analysis of the $N$. benthamiana healthy $(\mathrm{H})$ and infected (I) leaf tissue. Plant extract $(3 \mu \mathrm{l})$ diluted 1:100 (corresponds to the '100' point in C) was loaded onto the gradient 4 to $20 \%$ SDS-polyacrylamide gel, and, after separation, transferred to the nitrocellulose membrane and probed with the rabbit UID41 PAb at 1:20,000 dilution. $M$ designates the lane with protein markers; individual protein sizes are listed next to the bands. 

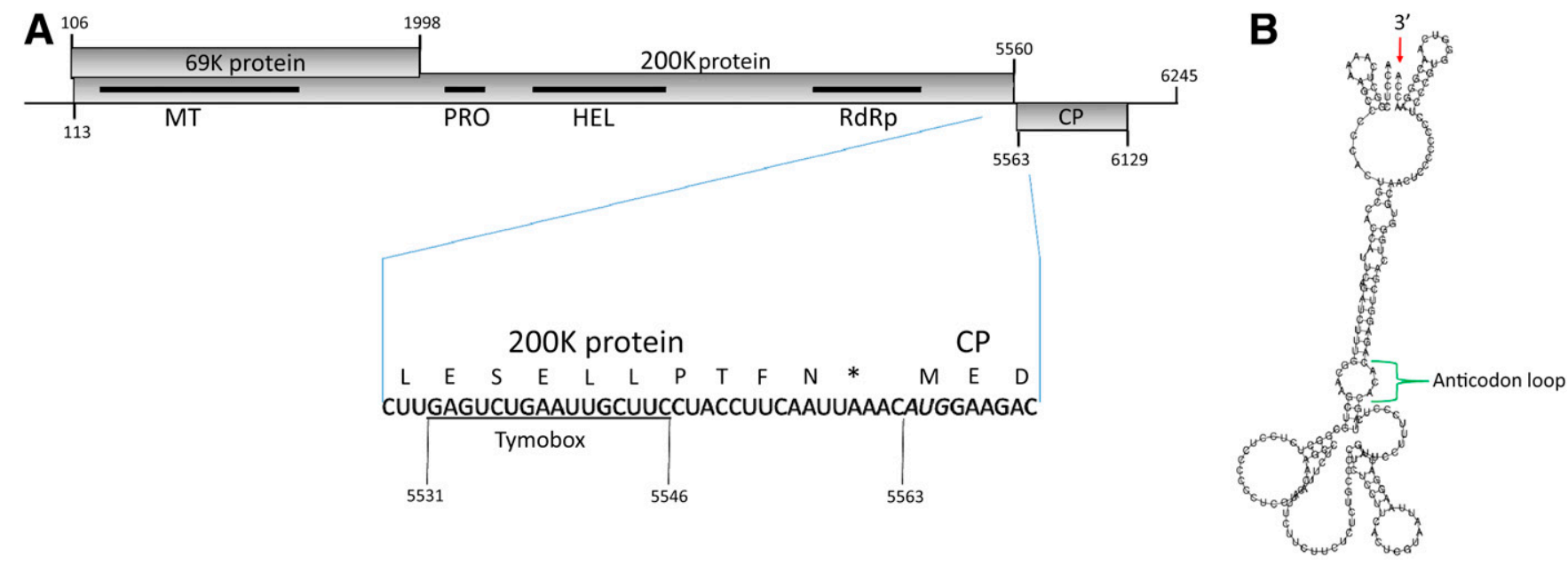

Fig. 3. A, Schematic diagram of the Naranillla chlorotic mosaic virus (NarCMV) genome organization. Positions of the three open reading frames coding for the 69-kDa (69K) protein, $200-\mathrm{kDa}(200 \mathrm{~K})$ protein, and capsid protein (CP) are shown as lightly shaded rectangles, with nucleotide numbers for the start and stop codons indicated. Solid rectangles indicate positions of the known protein domains identified in the 200K protein: methyltransferase (MT), protease (PRO), helicase (HEL), and RNA-dependent RNA polymerase (RdRp). Below the diagram, the sequence fragment between the 200K protein and CP genes is shown with the 16-nucleotide (nt) conserved 'tymobox' sequence underlined. B, Secondary structure prediction for the 3'-terminal 150-nt segment of the NarCMV genome, generated using the RNA-fold program (Lorenz et al. 2011). Positions of the $3^{\prime}$ terminus and the anticodon loop with the CAC valine anticodon are indicated with the arrow and the bracket, respectively.

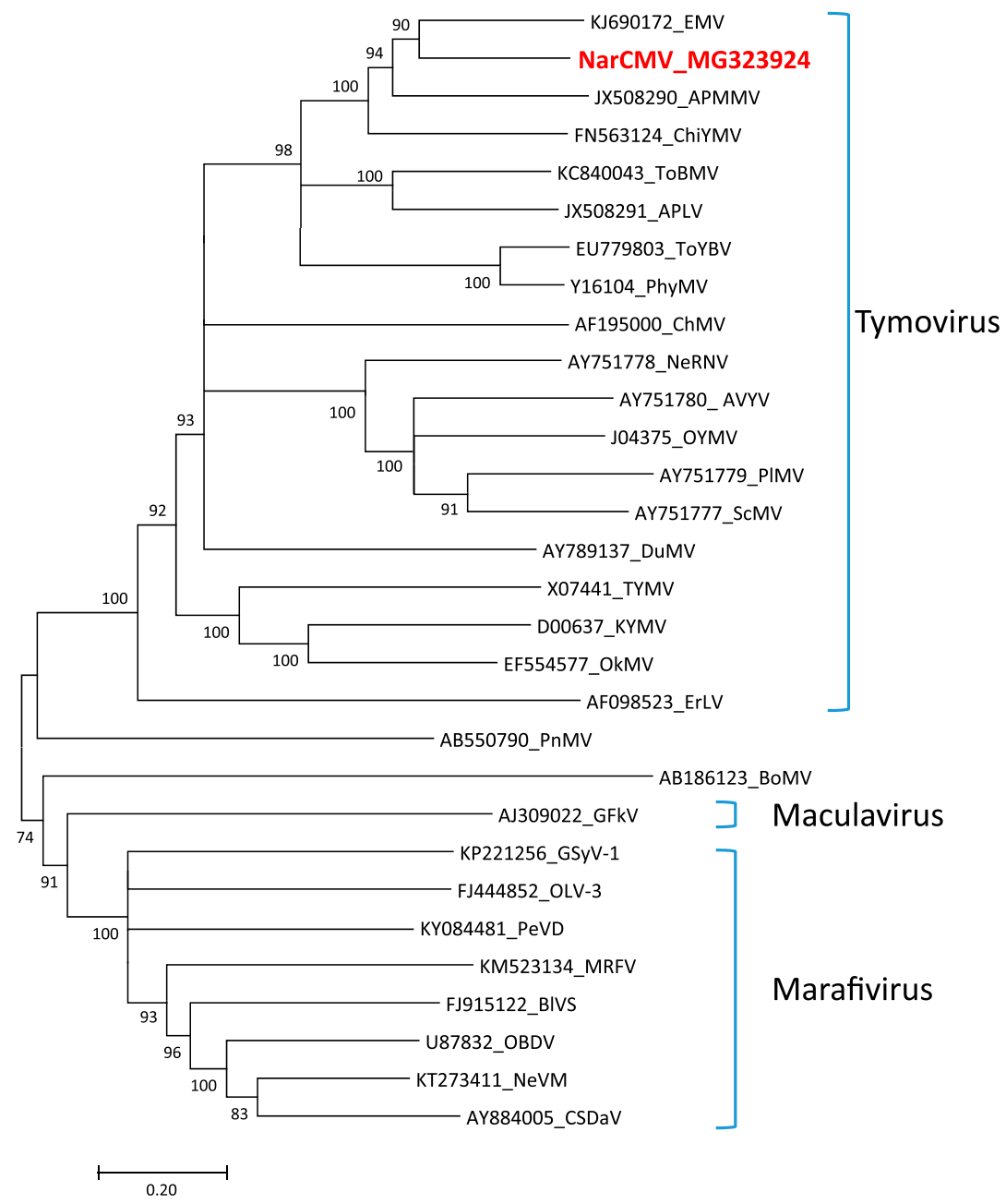

Fig. 4. Maximum-likelihood phylogenetic tree generated for whole-genome nucleotide sequences of the viruses from the family Tymoviridae. Bootstrap values exceeding $70 \%$ are shown at the respective nodes; nodes with values below $70 \%$ were collapsed. Brackets to the right designate established genera in the family. EMV = Eggplant mosaic virus, NarCMV $=$ Naranjilla chlorotic mosaic virus, APMMV = Andean potato mild mosaic virus, ChiYMV = Chiltepin yellow mosaic virus, ToBMV = Tomato blistering mosaic virus, APLV $=$ Andean potato latent virus, ToYBV = Tomato yellow blotch virus, PhyMV = Physalis mottle tymovirus, ChaMV $=$ Chayote mosaic tymovirus, NeRNV = Nemesia ring necrosis virus, AVYV $=$ Anagyris vein yellowing virus, OYMV = Ononis yellow mosaic virus, PIMV = Plantago mottle virus, ScMV = Scrophularia mottle virus, DuMV = Dulcamara mottle virus, TYMV $=$ Turnip yellow mosaic virus, $\mathrm{KYMV}=$ Kennedya yellow mosaic virus, OkMV $=$ Okra mosaic virus, ErLV $=$ Erysimum latent virus, PnMV $=$ Poinsettia mosaic virus, BoMV $=$ Bombyx mori macula-like virus, GFkV = Grapevine fleck virus, GSyV-1 = Grapevine Syrah virus 1, OLV-3 = Olive latent virus 3, PeVD $=$ Peach virus $D$, MRFV = Maize rayado fino virus, BIVS = Blackberry virus $S$, OBDV = Oat blue dwarf virus, $\mathrm{NeVM}=$ Nectarine virus $M$, and CSDaV = Citrus sudden death associated virus. 
the values for species demarcation in the family. This is the first report and complete characterization of a virus from naranjilla. The name Naranjilla chlorotic mosaic virus (NarCMV) is proposed, based on the symptoms induced in the original host.

The identification of NarCMV facilitates implementation of screening schemes for both breeding and virus-free certification programs, which are especially beneficial for vegetatively propagated crops. Determining the natural mode of NarCMV transmission requires further investigation. Several tymoviruses are known to be transmitted by flea beetles (Jones and Fribourg 1977; Markham and Smith 1949; Walters 1969; Weidemann and Bode 1973). In some known cases, however, mechanical transmission is more efficient than transmission by beetles, as demonstrated for Andean potato latent virus, a related tymovirus, infecting another solanaceous host (Jones and Fribourg 1977). The detection tools developed here, both ELISA and RT-PCR based, can now be applied to surveys of the viruses infecting naranjilla, and to studies of epidemiology of NarCMV.

\section{Acknowledgments}

We thank J. Durrin for providing potato tissue plantlets, J. Chojnacky for laboratory and greenhouse help, J. Mowery for assisting with TEM photography, G. Kinard for critically reading the manuscript, and the naranjilla growers in Pastaza (Ecuador) for allowing sampling in their orchards.

\section{Literature Cited}

Acosta, O., Pérez, A. M., and Vaillant, F. 2009. Chemical characterization, antioxidant properties, and volatile constituents of naranjilla (Solanum quitoense Lam.) cultivated in Costa Rica. Arch. Latinoam. Nutr. 59:88-94.

Alabdullah, A., Minafra, A., Elbeaino, T., Saponari, M., Savino, V., and Martelli, G. P. 2010. Complete nucleotide sequence and genome organization of Olive latent virus 3, a new putative member of the family Tymoviridae. Virus Res. 152:10-18.

Altschul, S. F., Gish, W., Miller, W., Myers, E. W., and Lipman, D. J. 1990. Basic local alignment search tool. J. Mol. Biol. 215:403-410.

Bozarth, C. S., Weiland, J. J., and Dreher, T. W. 1992. Expression of ORF-69 of turnip yellow mosaic virus is necessary for viral spread in plants. Virology 187: 124-130.

Chen, J., Li, W. X., Xie, D., Peng, J. R., and Ding, S. W. 2004. Viral virulence protein suppresses RNA silencing-mediated defense but upregulates the role of microrna in host gene expression. Plant Cell 16:1302-1313.

Clark, M. F., and Adams, A. N. 1977. Characteristics of the microplate method of enzyme-linked immunosorbent assay for the detection of plant viruses. J. Gen. Virol. 34:475-483.

Dellaporta, S. L., Woods, J., and Hicks, J. B. 1983. A plant DNA mini-preparation: Version II. Plant Mol. Biol. Rep. 1:19-21.

Dennis, F. G. J., and Herner, R. C. 1985. Naranjilla: A potential cash crop for the small farmer in Latin America. Acta Hortic. 158:475-481.

Ding, S., Keese, P., and Gibbs, A. 1990a. The nucleotide sequence of the genomic RNA of kennedya yellow mosaic tymovirus-Jervis Bay isolate: Relationships with potex- and carlaviruses. J. Gen. Virol. 71:925-931.

Ding, S. W., Howe, J., Keese, P., Mackenzie, A., Meek, D., Osorio-Keese, M., Skotnicki, M., Srifah, P., Torronen, M., and Gibbs, A. 1990b. The tymobox, a sequence shared by most tymoviruses: Its use in molecular studies of tymoviruses. Nucleic Acids Res. 18:1181-1187.

Ding, S. W., Keese, P., and Gibbs, A. 1989. Nucleotide sequence of the ononis yellow mosaic tymovirus genome. Virology 172:555-563.

Dreher, T. W. 2009. Role of tRNA-like structures in controlling plant virus replication. Virus Res. 139:217-229.

Dreher, T. W., Edwards, M. C., Gibbs, A. J., Haenni, A.-L., Hammond, R. W., Jupin, I., Koenig, R., Sabanadzovic, S., and Martelli, G. P. 2012. Family Tymoviridae. Pages 944-952 in: Virus Taxonomy. Ninth Report of the International Committee on Taxonomy of Viruses. A. M. Q. King, M. J. Adams, E. B. Carstens, and E. J. Lefkowitz, eds. Elsevier, Amsterdam.

Dunn, D. B., and Hitchborn, J. H. 1965. The use of bentonite in the purification of plant viruses. Virology 25:171-192.

Edgar, R. C. 2004. MUSCLE: multiple sequence alignment with high accuracy and high throughput. Nucleic Acids Res. 32:1792-1797.

Edwards, M. C., Weiland, J. J., Todd, J., and Stewart, L. R. 2015. Infectious Maize rayado fino virus from cloned cDNA. Phytopathology 105:833-839.

Edwards, M. C., Zhang, Z., and Weiland, J. J. 1997. Oat blue dwarf marafivirus resembles the tymoviruses in sequence, genome organization, and expression strategy. Virology 232:217-229.

Espinoza, D., Viera, W., Debut, A., Vásquez, W., and Ayala, L. 2017. Virus diagnosis in tree tomato (Solanum betaceum Cav.) by RT-PCR and transmission electron microscopy in Pichincha and Tungurahua Provinces of Ecuador. Agron. Colomb. 35:35-43.

Gancel, A. L., Alter, P., Dhuique-Mayer, C., Ruales, J., and Vaillant, F. 2008. Identifying carotenoids and phenolic compounds in naranjilla (Solanum quitoense Lam. var. Puyo hybrid), an Andean fruit. J. Agric. Food Chem. 56: 11890-11899.

Glasa, M., Predajna, L., Soltys, K., Sabanadzovic, S., and Olmos, A. 2015. Detection and molecular characterisation of Grapevine Syrah virus-1 isolates from Central Europe. Virus Genes 51:112-121.

Green, K. J., Brown, C. J., Gray, S. M., and Karasev, A. V. 2017. Phylogenetic study of recombinant strains of Potato virus $Y$. Virology 507:40-52.

Hanson, A. J., Guho, N. M., Paszczynski, A. J., and Coats, E. R. 2016. Community proteomics provides functional insight into polyhydroxyalkanoate production by a mixed microbial culture cultivated on fermented dairy manure. Appl. Microbiol. Biotechnol. 100:7957-7976.

Heiser, C. B., and Anderson, G. 1999. "New" Solanums. Pages 379-384 in: Perspectives on New Crops and New Use. J. Janick, ed. ASHS Press, Alexandria, VA.

Insuasti, M., Ochoa, J., Martin, R., Álvarez, R., and Quito, D. 2016. First Report of Potato virus $V$ and Peru tomato mosaic virus on Tamarillo (Solanum betaceum) orchards of Ecuador. Plant Dis. 100:868.

Integrated Pest Management Innovation Lab. 2013. Naranjilla grafting in Ecuador: Reducing deforestation and promoting the growth of an industry. Online publication. http://ipmil.oired.vt.edu/wp-content/uploads/2013/04/naranjillagrafting-in-ecuador-2014-updates.pdf

Jones, R. A. C., and Fribourg, C. E. 1977. Beetle, contact and potato true seed transmission of Andean potato latent virus. Ann. Appl. Biol. 86:123-128.

Karasev, A. V., Nikolaeva, O. V., Hu, X., Sielaff, Z., Whitworth, J., Lorenzen, J. H., and Gray, S. M. 2010. Serological properties of ordinary and necrotic isolates of Potato virus Y: a case study of PVYN misidentification. Am. J. Potato Res. 87:1-9.

Katsuma, S., Tanaka, S., Omuro, N., Takabuchi, L., Daimon, T., Imanishi, S., Yamashita, S., Iwanaga, M., Mita, K., Maeda, S., Kobayashi, M., and Shimada, T. 2005. Novel macula-like virus identified in Bombyx mori cultured cells. J. Virol. 79:5577-5584

Koenig, R., Barends, S., Gultyaev, A. P., Lesemann, D. E., Vetten, H. J., Loss, S. and Pleij, C. W. 2005a. Nemesia ring necrosis virus: A new tymovirus with a genomic RNA having a histidylatable tobamovirus-like $3^{\prime}$ end. J. Gen. Virol $86: 1827-1833$

Koenig, R., and Lesemann, D.-E. 1979. Tymovirus group. Descriptions of Plant Viruses, No. 214. Association of Applied Biologists, Wellesbourne, Warwick, UK. http://www.dpvweb.net/dpv/showdpv.php?dpvno=214

Koenig, R., Pleij, C. W., Lesemann, D. E., Loss, S., and Vetten, H. J. 2005b Molecular characterization of isolates of anagyris vein yellowing virus, plantago mottle virus and scrophularia mottle virus-Comparison of various approaches for tymovirus classification. Arch. Virol. 150:2325-2338.

Kreuze, J., Koenig, R., De Souza, J., Vetten, H. J., Muller, G., Flores, B., Ziebell, H., and Cuellar, W. 2013. The complete genome sequences of a Peruvian and a Colombian isolate of Andean potato latent virus and partial sequences of further isolates suggest the existence of two distinct potato-infecting tymovirus species. Virus Res. 173:431-435.

Kumar, S., Stecher, G., and Tamura, K. 2016. MEGA7: Molecular Evolutionary Genetics Analysis Version 7.0 for Bigger Datasets. Mol. Biol. Evol. 33: 1870-1874.

Lorenz, R., Bernhart, S. H., Hoener zu Siederdissen, C., Tafer, H., Flamm, C., Stadler, P. F., and Hofacker, I. L. 2011. ViennaRNA Package 2.0. Algorithms Mol. Biol. 6:26.

Maccheroni, W., Alegria, M. C., Greggio, C. C., Piazza, J. P., Kamla, R. F. Zacharias, P. R., Bar-Joseph, M., Kitajima, E. W., Assumpcao, L. C. Camarotte, G., Cardozo, J., Casagrande, E. C., Ferrari, F., Franco, S. F., Giachetto, P. F., Girasol, A., Jordao, H., Jr., Silva, V. H., Souza, L. C., Aguilar-Vildoso, C. I., Zanca, A. S., Arruda, P., Kitajima, J. P., Reinach, F. C., Ferro, J. A., and da Silva, A. C. 2005. Identification and genomic characterization of a new virus (Tymoviridae family) associated with citrus sudden death disease. J. Virol. 79:3028-3037.

Markham, R., and Smith, K. M. 1949. Studies of the virus of turnip yellow mosaic. Parasitology 39:330-342.

Monteros, A., Munoz, L., Revelo, J., Tapia, C., Zambrano, E., Fiallos, J., and Kodym, A. 2004. Nematode resistance through mutation induction in a local variety of Naranjilla (Solanum quitoense Lam) in Ecuador (IAEATECDOC-1426). International Atomic Energy Agency (IAEA), Vienna, Austria.

Morch, M. D., Boyer, J. C., and Haenni, A. L. 1988. Overlapping open reading frames revealed by complete nucleotide sequencing of turnip yellow mosaic virus genomic RNA. Nucleic Acids Res. 16:6157-6173.

Nikolaeva, O. V., Roop, D., Galvino-Costa, S. F. B., Figueira, A. R., Gray, S. M., and Karasev, A. V. 2012. Epitope mapping for monoclonal antibodies recognizing tuber necrotic strains of Potato virus Y. Am. J. Potato Res. 89: 121-128.

Ochoa, J. C., Yangari, B., Galarza, V., Fiallos, J., and Ellis, M. A. 2001. Vascular wilt of common naranjilla (Solanum quitoense) caused by Fusarium oxysporum in Ecuador. Online publication. Plant Health Prog. doi.org/10.1094/PHP-20010918-01-HN.

Okano, Y., Maejima, K., Shiraishi, T., Hashimoto, M., Senshu, H., Ozeki, J., Takahashi, S., Komatsu, K., Yamaji, Y., and Namba, S. 2010. Genetic heterogeneity found in the replicase gene of poinsettia mosaic virus isolates. Arch. Virol. 155:1367-1370. 
Osorio-Keese, M. E., Keese, P., and Gibbs, A. 1989. Nucleotide sequence of the genome of eggplant mosaic tymovirus. Virology 172:547-554.

Pagán, I., Betancourt, M., de Miguel, J., Piñero, D., Fraile, A., and García-Arenal, F. 2010. Genomic and biological characterization of chiltepín yellow mosaic virus, a new tymovirus infecting Capsicum annum var. aviculare in Mexico. Arch. Virol. 155:675-684.

Sabanadzovic, S., and Abou Ghanem-Sabanadzovic, N. 2009. Identification and molecular characterization of a marafivirus in Rubus spp. Arch. Virol. 154:1729-1735.

Sabanadzovic, S., Abou Ghanem-Sabanadzovic, N. A., Saldarelli, P., and Martelli, G. P. 2001. Complete nucleotide sequence and genome organization of Grapevine fleck virus. J. Gen. Virol. 82:2009-2015.

Srifah, P., Keese, P., Weiller, G., and Gibbs, A. 1992. Comparisons of the genomic sequences of erysimum latent virus and other tymoviruses: A search for the molecular basis of their host specificities. J. Gen. Virol. 73:1437-1447.
Stephan, D., Siddiqua, M., Ta Hoang, A., Engelmann, J., Winter, S., and Maiss, E. 2008. Complete nucleotide sequence and experimental host range of Okra mosaic virus. Virus Genes 36:231-240.

Tzanetakis, I. E., Tsai, C. H., Martin, R. R., and Dreher, T. W. 2009. A tymovirus with an atypical 3 '-UTR illuminates the possibilities for $3^{\prime}$-UTR evolution. Virology 392:238-245

Villamor, D. E. V., Mekuria, T. A., Pillai, S. S., and Eastwell, K. C. 2016. Highthroughput sequencing identifies novel viruses in nectarine: Insights to the etiology of stem pitting disease. Phytopathology 106:519-527.

Walters, H. J. 1969. Beetle transmission of plant viruses. Adv. Virus Res. 15 339-363.

Weidemann, H. L., and Bode, O. 1973. Untersuchungen über ein neues isometrisches Virus aus Atropa belladonna L. IV. Versuche zur Übertragbarkeit des Belladonna mottle virus. Phytopathol. Z. 76:6-10. 